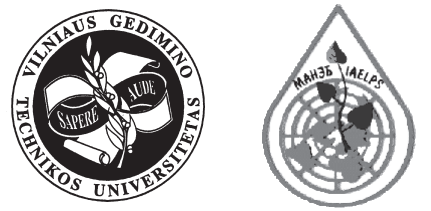

\title{
RELATIONSHIP BETWEEN NITRATE AMOUNT IN GROUNDWATER AND NATURAL FACTORS
}

\author{
Alma Pociené1, Skirmantas Pocius ${ }^{2}$ \\ ${ }^{1}$ Dept of Land Reclamation, Faculty of Water and Land Management, Lithuanian University of Agriculture, \\ Universiteto g. 10, LT-53361 Kaunas-Akademija, Kauno r., Lithuania.E-mail: almap@hidro.lzuu.lt \\ ${ }^{2}$ Alytus Region Dept of Enviromental Protection, Prienai Environmental Protection Agency, Kęstučio g. 32, \\ LT-59129 Prienai, Lithuania.E-mail: s.pocius@ard.am.lt
}

Received 19 Nov 2004; accepted 14 Dec 2004

\begin{abstract}
In Lithuania almost the whole drinking water is derived from groundwater sources. The concept of groundwater vulnerability is based on an assumption that a physical environment may provide some degree of protection to groundwater against human impact.The earth materials may act as natural filters to screen out some contaminants. Groundwater vulnerability depends on the natural characteristics of a site and relates to the pathways and rate of downward movement of pollutants. Pollutant migration through the soil zone depends just on the depth of waterlogging, texture, organic matter content, quantity of precipitation.. Pollutants accumulating in shallow groundwater in the Lithuanian area are, first of all, nitrates and organic matter. Regularities of groundwater chemistry can be determined only after investigation into the processes of their formation. That is why we need to find out the main factors of nitrate concentrations in groundwater. Investigation took place in Karkiškès object of Educational Farm of Lithuanian University of Agriculture in 1997-2002. Also, the data from publications were used. The regime of groundwater level and the quantity of nitrates in it was an object of the investigation. The objective of the thesis is to estimate correlation between nitrate concentrations in groundwater and natural factors, such as textural composition of the soil, the quantity of clay and humus particles in the soil, the depth up to the groundwater level, the depth of a restrictive layer and annual precipitation amount. The correlation analysis was used to determine relationship among these factors. The investigation shows that the concentration of nitrogen in groundwater and nitrate leaching are under the influence of humus and clay particles in the soil. It also shows that, when the content of clay particles in the soil increases, nitrogen leaching decreases. Relationship between nitrate content in groundwater and its level from the soil surface, precipitation amount were identified by the investigation. The obtained relationship is close enough, and the correlation coefficients are high $(0,86-0,98)$.
\end{abstract}

Keywords: groundwater, pollution, nitrate, natural factors, precipitation, humus, quality of water, impervious layer.

\section{Introduction}

For ensuring a rational environment and planning of groundwater protection, it is necessary to perceive the functioning mechanism of a system called "poluttants - natural environment", to investigate pollution influence on the environment and natural environment possibilities to make pollutants harmless.

Groundwater degrades when the changes of its quality parametres exceed natural fluctuations. A physical environment may provide some degree of protection to groundwater against human impact. The earth materials may act as natural filters to screen out some contaminants.

In Lithuania the thickness of the soil layer reaches
1,5 metres. Groundwater mostly lies at a depth of onethree metres, and its level fluctuates at an average depth of $0,2-5,0$ metres. The fluctuations depend on seasons [1].

The chemical composition of groundwater and its change caused by economic activities are important for three reasons:

1. Lithuanian rivers drain groundwater that forms the main river flow during summer droughts and winter frosts. Also, the chemical composition of river water is decided by groundwater;

2. In Lithuania a lot of citizens (about 1 million), that live on individual farms, villages and outskirts of towns, use groundwater for drinking, household and domestic animal feeding. 
Classification of Quaternary deposits

\begin{tabular}{|c|c|l|}
\hline Categories & Permeability & \multicolumn{1}{c|}{ Deposits } \\
\hline A & Particularly high & Gravel, sand and gravel, including aeolian and alluvial sand \\
\hline B & High & Sand (excluding the above mentioned) \\
\hline C & Intermediate & Aleurite, peat and moraine (excluding ground moraine) \\
\hline D & Low & Ground moraine and limnoglacial clay \\
\hline
\end{tabular}

3. Groundwater arrives at artesian aquifers through impermeable layers by a pathway of breaches vertically and has an influence on the chemical composition of their water. This water is used by all citizens [2].

In Lithuania groundwater is one of the main resources of drinking water. Decline in groundwater quality can directly affect human health. In many areas the quality of groundwater is an inconsiderable concern. The facts show that in Lithuania groundwater is most of all polluted with nitrogen compounds [3, 4].

Water is contaminated with pesticides and mineral fertilizers that are used in agriculture. Not all of mineral fertilizers that fall on the soil are adopted by plants. Some part together with rainwater go to streams, ditches, lakes. Good conditions for weed growing in water bodies occur. Some part of mineral fertilizers goes to groundwater, and this causes decrease of water quality in wells.

Lithuanian hydrogeologists' investigations show that the pollution of groundwater becomes regional. Groundwater taking intermediate position between surface and artesian water help to stem and transform contaminants. They also protect artesian and surface water that are used for drinking and other modes of life. The fluctuations of groundwater chemical composition and level regime give information about coming deformations of the appropriate ecosystem [4]. It means that groundwater can serve as an indicator of a big sensibility that senses the beginning of deflection of ecosystem from balance. For this reason groundwater is treated as one of underlying objects in a water-monitoring system. That is why we need to find out the main factors of nitrate concentrations in groundwater.

Qualitative changes of groundwater and their pollution level are caused by their vulnerability. N. P. Achmetjeva points out two sorts of vulnerability. The first one, called common vulnerability, is conditioned by natural factors. The second one, called special vulnerability, depends on relationship with particular polluters [5].

For analysing the vulnerability problems of groundwater, researchers study several factors that have a different meaning in estimating potential pollution of groundwater. These factors are: filtration characteristics of the upper layer of the soil, aeration zone ground and aquifer, the depth up to the groundwater level, relief and others. Some of these factors are under consideration, others are disregarded. N. P. Achmetjeva notices that many researchers maintain that the main factors of unconfined aquifers, that condition the vulnerability of groundwater, are the depth of groundwater level, aera- tion zone permeability and infiltration feeding and water change period. Others point out sorption, the time period when pollutants infiltrate up to the groundwater level, and dilution as prior factors [5].

Most of the main Lithuanian aquifers, which can be accessed by pollutants, are in Quaternary age deposits. Vulnerability assessment is based on a 3-fold soil leaching potential classification superimposed on a 4fold permeability classification of Quaternary geological deposits. Soil Leaching Potential is a measure of a relative speed of pollutant migration through the soil zone and depends just on the following factors: depth, duration and type of water logging, texture, organic matter content. Classification is based on Quaternary deposit permeability that reflects pollutant penetration up to groundwater possibilities in groundwater vulnerability maps (Table)[6].

Soil Leaching Potential (SLP) was formed according to the soil layer influence on pollutant migration [6]. SLP is a dimension which shows the easiness of pollutant penetration down through the soil profile in the light of soil characteristics that can cause pollutant dilution or their absorption.

Formation of drain water chemical composition, the leaching of nutriment substances depending on soil, climate, plant vegetation, fertilization, depth of drainage is investigated [7-9]. The objective of our work is to determine relationship between nitrate concentrations in groundwater and the main natural factors, such as the quantity of clay particles in the soil, the depth of groundwater level, the quantity of humus in the soil, precipitation amount and granulometric composition of the soil. Estimation of the above- mentioned relationships would give possibility to evaluate natural environmental opportunities to depurate from pollution. From an ecological point of view an important indicator is the quantity of nitrate ions in groundwater [10]. Drinking water that has more than $10 \mathrm{mg} / \mathrm{l}$ of nitrate nitrogen is dangerous for human health, especially for babies [11,12].

\section{Materials and methods}

The subject of the investigation is groundwater as well as correlation and relationship between the contaminants of groundwater and a natural environment.

This paper is a theoretical summarization of the authors' investigations where the methods of correlation analysis were used.

Investigative variables. The period of the investigation is 1997-2002. The nitrate quantity in groundwa- 
ter was tested depending on the granulometric composition of the soil, quantity of humus in the soil, quantity of clay particles in the aeration zone soil, amount of precipitation and depth of groundwater level.

Data types and sources. The data of the investigation performed by the authors in Karkiškès experimental drainage systems in Educational Farm of Lithuanian University of Agriculture and those from literature were used. Also, data from the underground hydrosphere monitoring stations of the Ministry of Environment were used. The investigation took place in 1997-2002 in Karkiškès object, Kaunas region. The area of the object is 4,31 ha. Drainage is made of clay tiles. The tile drains are situated at a depth 1,1 m and spacing of $18 \mathrm{~m}$. In 1994 the drainage was reconstructed in the experimental object. The ditch was sewered, some drainage was reformed. In Karkiškès the soils are sandy loam and loamy sand. According to genetic composition the soils are ascribable to Hapli - Endohypogleyic Luvisols. The bulk density of soil varies between 1,28 and $1,73 \mathrm{~g} / \mathrm{cm}^{3}$. The hydraulic conductivity of $20-40 \mathrm{~cm}$ layer is $0,23-0,24 \mathrm{~m}$ per day. $\mathrm{pH}-6,5-7,0$. The quantity of humus in the topsoil was 2,1-2,3 percent. In 1997 a detailed hydrogoelogical area investigation took place in the investigation object. The section method was used, and it was established that an impermeable layer occurs at a depth of 2,0-2,7 meters. During the investigation the conditions of groundwater formation and opportunities of fixed groundwater inflow to the experimental object were established. The investigation material shows that the groundwater formed from rainfall waters in this object. For this reason the groundwater regime mostly depends on rainfall.

Groundwater pressure was measured in six pjezometer pipes at a depth of 2,5 meters. Samples for nitrate concentration measurement were taken from the pjezometers. The groundwater level was measured and water samples were taken every 10 days. The samples were taken and transported according to Lithuanian Standard requirements $[13,14]$. Meteorological data were taken from Kaunas Agro-meteorological Station which is situated at about more than $0,5 \mathrm{~km}$ from the experimentation field.

\section{Investigation results}

An especially wide variety is typical of groundwater composition even in small areas. The main reason of this phenomenon is a double infiltration mechanism. The substantiality of it consists of two factors. The first factor is a slow migration of water and pollutants in an aeration zone. An average speed is about 1 meter per year. During migration intensive transformation and degradation of pollutants is in progress. The second factor is existence of infiltration of fast ways in an aeration zone. In this instance practically unclean pollution reaches the groundwater horizon at a speed of $0,6-0,8$ meters per day [15].
The flow of water and nitrates from an aeration zone to groundwater is caused by the aquifer depth and characteristics. Water from agricultural fields often reaches groundwater a lot of years later. It can take from 10 to 80 years [16].

During the investigation of pollutant permeability possibilities up to groundwater the soil physical properties were used. The soil can be an absorption barrier for chemical substances with a lot of humus, clay and colloidal particles. Practically it collects all the elements that are in solution.

The chemical composition and quality of groundwater mostly depends on the soils accumulated in groundwater. The infiltration of atmospheric precipitation is the only way for various substances to reach the aquifer. Precipitation contains much less melting substances than underground water.

A. Tyla maintains that precipitation of weak mineralization falls on the soil surface. This precipitation contains few main biogenic elements, except sulfates, and the concentration of nitrates is comparatively small (the average is $2,8 \mathrm{mg} / \mathrm{l}$ ) [17]. But during filtration to aquifer precipitation dissolves a lot of various substances that are gathered on the soil surface, particularly in soil layers. The chemical composition of precipitation that reaches groundwater depends on the fall time very much because economic activity and its intensity are different during various seasons. That is why even a small change of annual rainfall can evoke particular changes in indicators of chemical water composition.

In Lithuania two types of aeration zones dominate. They are sandy and clayey. Sandy sediments transmit pollutants easily, but they are not favorable for accumulation of pollutants. In an environment with a lot of oxygen pollutants are oxygenated (dissoluble).

Groundwater pollution in clayey formations is higher than in well-drained sandy plains. It is well known that this regularity is a result of geological-hidrogeological factors water-bearing sediments, duration of water-rock contact and groundwater circulation rate [15]. The concentration of nitrates in shallow groundwater contained in sandy and clayey sediments in 2002 was, respectively, $12 \mathrm{mg} / \mathrm{l}$ and $15 \mathrm{mg} / \mathrm{l}$ [18]. A. Motuzas maintains that "the heavier the granulometric composition of the soil, the higher ion concentration in its drainage water, and also the common quantity of salts"[10].

Our statistical data analysis show that the quantity of leached nitrogen depends on the quantity of clay particles in the aeration zone soil (Fig 1). Nitrogen is mostly leached from soils that have less quantity of clay particles.

The obtained relationship is

$$
y=291,14 x^{-0,5437},
$$

where $x$ - percentage of clay particles, $y$ - quantity of leached nitrogen per year $(\mathrm{kg} / \mathrm{ha})$.

The investigation shows that, when the quantity of clay particles increases by $25-31 \%$, the annual quantity 
of leached nitrogen with drainage runoff increases almost twice in ploughed up pasture ecosystems. But further, if the quantity of clay particles increases more, less nitrogen is leached [9].

The researchers of Lithuanian University of Agriculture investigated nitrate concentration in wells, depending on the granulometric composition of sediments in Kaunas region, Pypliai village [19]. According to their data, the maximum average quantity of $\mathrm{NO}_{3}$ was $65 \mathrm{mg} /$ 1 in a well of $\mathrm{D}$ category sediment. In wells of $\mathrm{B}$ and $\mathrm{C}$ category sediment the average quantities of $\mathrm{NO}_{3}$ were, respectively, $12 \mathrm{mg} / \mathrm{l}$ and $43 \mathrm{mg} / \mathrm{l}$.

Clay particles tend to absorb an organic substance on their surface. For this reason a part of it was eliminated in the aeration zone.

Average values of permanganate oxidation in $\mathrm{B}, \mathrm{C}$, D category sediment were, respectively, 6,2, 3,2 and 2,3 $\mathrm{mg} / \mathrm{l} \mathrm{O}$ [19].

With reference to our investigation data and those from literature, we analysed correlation between leached nitrogen quantity and the quantity of humus in an arable soil layer [20]. The data analysis shows that the influence of humus on the quantity of leached nitrogen also depends on cultivated plants (Fig 2). In lysimeter with perennial grass a bigger quantity of humus stimulated a bigger nitrogen leaching. In an agricultural crop rotation field the influence of humus quantity was opposite. Growing quantity of humus in an arable soil layer caused a decrease of nitrogen leaching. The correlation is not so high $(0,61-0,58)$, but tough enough to show the existing relationship.

In 1998 in Karkiškès experimental object barley with sowed clover were grown. On the $15^{\text {th }}$ of May barley was fertilized with ammonium nitre, on the $20^{\text {th }}$ of May we took a sample of groundwater and estimated an increase of nitrate concentration from $25,0 \mathrm{mg} / 1$ up to $30,0 \mathrm{mg} / \mathrm{l}$. On that day the groundwater was at a depth of 1,04-1,49 meters in the experimental object. Such a fast change of nitrate concentration was caused by the soil humidity. Throughout the whole profile of the soil its humidity was near the field capacity. A close relation between upper soil layers and groundwater exists when the soil humidity is like this. The way from the soil surface up to groundwater of rainfall filtration depends on the depth of groundwater.

The less the depth of groundwater level, the shorter

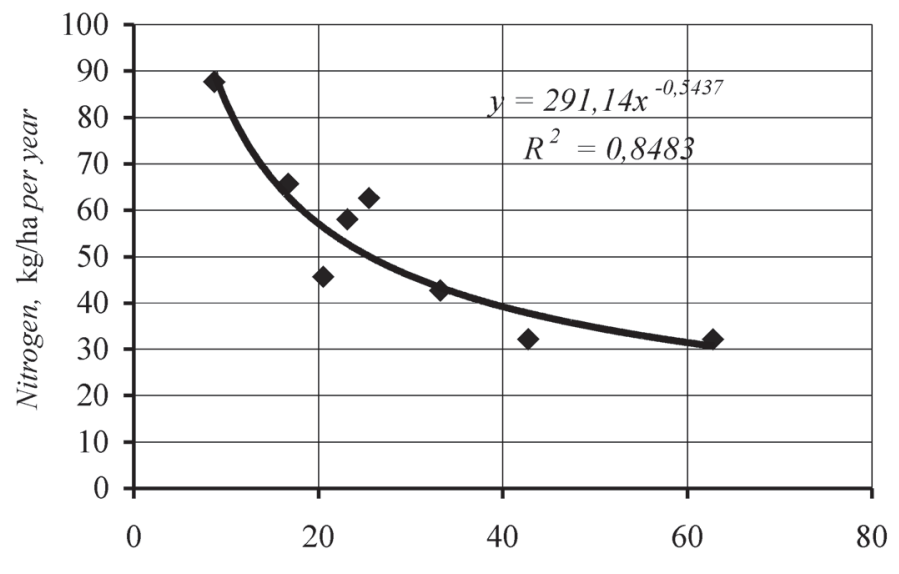

Percentage of clay particles

Fig 1. Relationship between leached nitrogen amount and average content of clay particles in $0-135 \mathrm{~cm}$ deep soil layer

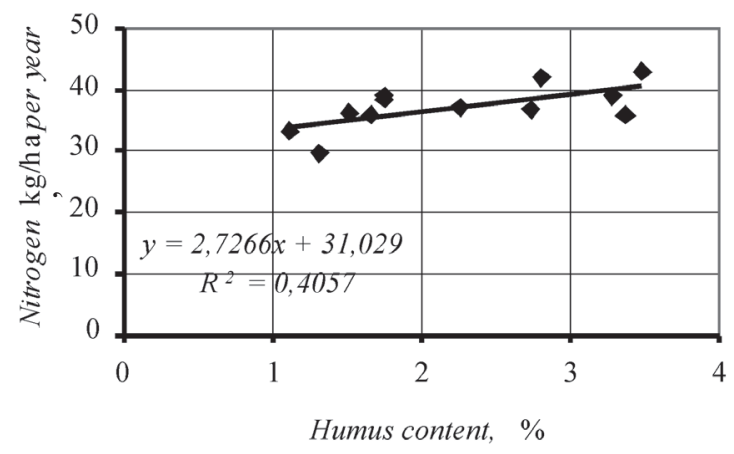

b

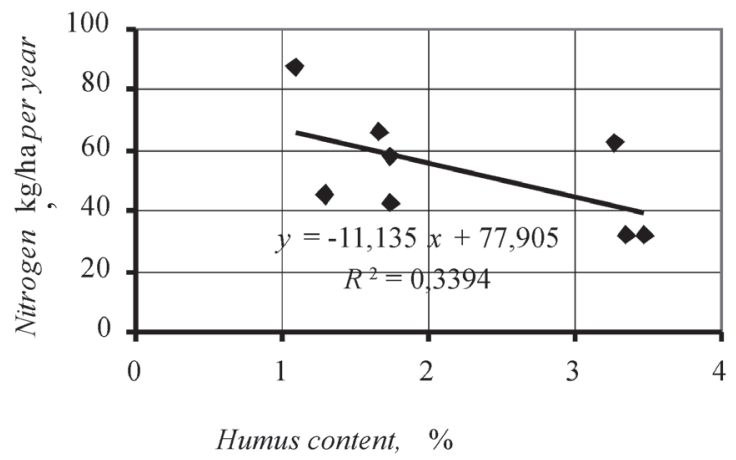

Fig 2. Relationship between leached nitrogen amount and humus content in arable soil layer: a - lysimeter with perennial grass; $\mathrm{b}$ - lysimeter with six-field crop rotation 
way of filtration up to it, and the more precipitation and plant nutritious substances melt in water (also nitrogen) reach groundwater.

The investigation data were analysed, and the result is the following relationship between the depth of groundwater level and nitrate quantity in groundwater (Fig 3):

$$
y=40,977 x^{-4,146}
$$

where $x$-depth of groundwater from soil surface, $\mathrm{m} ; y$ - quantity of nitrates in water, $\mathrm{mg} / \mathrm{l}$, when $R^{2}=0,743$.

Geohydrological conditions are one more important factor of water formation. In the experimental object an impervious layer is situated at a depth of 2,02,7 meters. It was important for us to evaluate the influence of the depth of a restrictive layer on the pollutant quantity in groundwater.

The investigation data (Fig 4) show that the influence of an impervious layer depth on the quantity of nitrates in groundwater appears in spring and autumn, when the level of ground- water is nearer to the land surface. When an impervious layer is at a depth of $2,7 \mathrm{~m}$, the quantity of nitrates in groundwater changes very little, and during the investigation in 1998 the quantity of nitrates in groundwater did not exceed $7,0 \mathrm{mg} / \mathrm{l}$. In groundwater that was on a restrictive layer of $2,0 \mathrm{~m}$ depth the concentration of nitrates fluctuated from $50,1 \mathrm{mg} / \mathrm{l}$ up to $2,6 \mathrm{mg} / \mathrm{l}$ during the same period.

The same results were obtained next year. When a restrictive layer is shallower water reaches it faster and accumulates there. On a restrictive layer that is nearer to the land surface a thinner layer of groundwater accumulates, and pollutants are less attenuated.

One of determinant factors of nitrate quantity in groundwater is rainfall. That is why we tried to estimate correlation between annual rainfall and an average annual nitrate content in groundwater in Karkiškès experimental object (Fig 5). The investigation shows that an average nitrate concentration in groundwater confidently correlates with annual precipitation.

The investigation data show that relationship between the quantity of nitrates in groundwater and rainfall is:

$$
\begin{gathered}
y=0,0857 x-26,387, \\
R^{2}=0,9644,
\end{gathered}
$$

where $x$ - annual rainfall, $\mathrm{mm} ; y$ - average annual nitrate quantity in groundwater, $\mathrm{mg} / \mathrm{l}$.

The correlation is direct, that is the higher annual rainfall, the higher nitrate concentration in groundwater.

The data on state monitoring of groundwater in

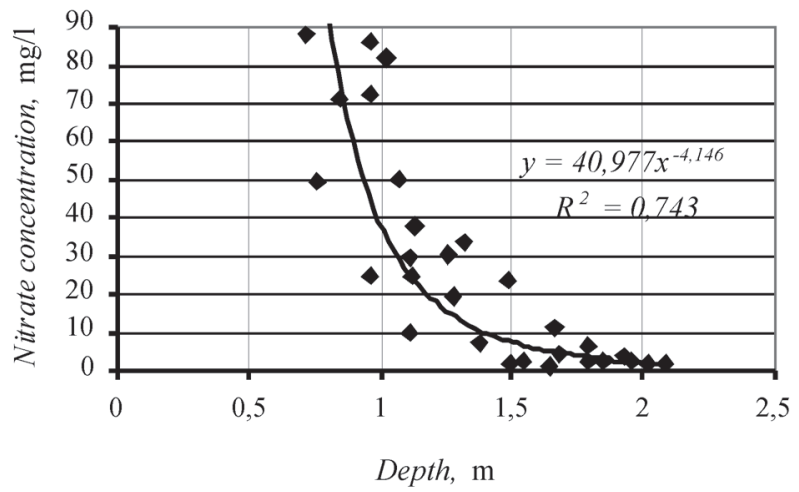

Fig 3. Relationship between nitrate quantity in groundwater and its level from soil surface
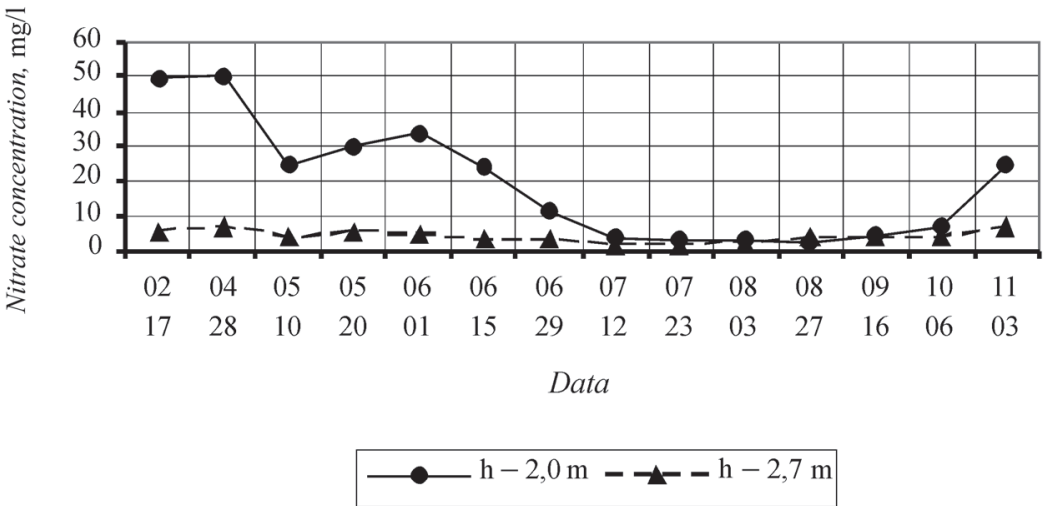

Fig 4. Content of nitrates in groundwater in relation to impervious layer depth 


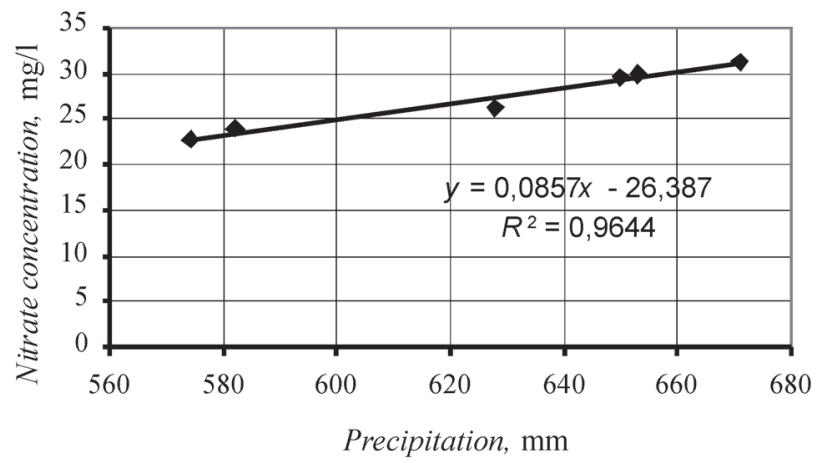

Fig 5. Relationship between average annual nitrate concentration in groundwater and annual precipitation amount

1995-2002 show that the least pollution with nitrates was observed in 1995, and the highest one - in 19961997. There are no clear tendencies to a fixed increase or decrease of nitrate distribution [18].

The quantity of nitrates in groundwater is influenced not only by natural factors but by anthropogenic loads as well. Our objective was not to accomplish investigation that is related to anthropogenic loads. For this reason we used the data of Geological Survey. The investigation shows that in 1997 the average values of nitrates in Alanta and Mockūnai monitoring stations were the biggest $(124,2-70,49 \mathrm{mg} / \mathrm{l})$. In these areas besides common agricultural pollution different intensive human activities were signified [20].

In 2002 an enormous nitrate concentration (up to $139 \mathrm{mg} / \mathrm{l}$ ) was observed in Kudirkos Naumiestis monitoring station. This station is in a rural area [18]. According to comparison of the statistical rate of nitrate quantity of groundwater in a forest and farmland, the parameters are, respectively: the average $-2,41 \mathrm{mg} / 1$ and $12,27 \mathrm{mg} / \mathrm{l}$, the maximum - 14,07 $\mathrm{mg} / \mathrm{l}$ and $121,16 \mathrm{mg} / \mathrm{l}$, the minimum $-0,00 \mathrm{mg} / \mathrm{l}$ for both cases [21].

The investigation shows that transportation of contaminants in an aeration zone depends mainly on moisture migration. Moisture exchange in a sandy soil is vertical for a partly saturated zone, and horizontal - for an entirely saturated zone. Whereas in loam deposits moisture migration in both zones is mostly vertical [1].

The investigation performed shows that having data on groundwater formation sources, the tendencies and direction of contaminant spreading can be forecasted. In a sandy plain there is a risk to pollute groundwater of lager areas because a lateral flow prevails and transports pollutants in a horizontal direction. A totally different situation is in a loamy lowland. Here a soil of small permeability prevails, and horizontal spreading of pollutants is not substantial. The spread concentrates locally in a pollution source and moves mostly vertically. Here pollution is especially dangerous for lower aquifers [1].

\section{Conclusions}

1. For ensuring rational groundwater protection plan- ning, it is necessary to perceive the functioning mechanism of a system called "pollutants - natural environment". Investigation of the natural environment effect on groundwater pollution helps to solve many ecological problems.

2. Pollution of groundwater with nitrates depends on natural water formation circumstances. Differences in water pollution are mostly determined by the soil texture in subsoil and sublayer, geohydrological conditions.

3. Important correlation among the depth of groundwater level, annual precipitation amount and nitrate concentration in groundwater were estimated $(R=0,87-$ $0,98)$.

4. The quantity of leached nitrates depends on the content of clay particles in an aeration zone and humus content in an arable soil layer $(R=0,84-0,61)$.

\section{References}

1. Žemaitis, V. Migration of moisture and contaminants in an aeration zone. Vilnius, 1993, 32 p.

2. Ecological sustainability of Region Historical Context: an example of Lithuania. State Science Programme of Lithuania, I part (Chief of the work V. Kairiūkštis). Vilnius, 1997, p 272-284 (in Lithuanian).

3. Kadūnas, K.; Mašanauskas, V. Farming and ground water quality. In: Farming and water quality. Proceedings. Kaunas, 1992, p 32-34 (in Lithuanian).

4. Šaltenienè, A.; Prentkovskis, O. Experimental investigation of substance concentration changes when filtering water with filters. Journal of Environmental Engineering and Landscape Management, Vol XII, No 2, Vilnius: Technika, 2004, p 71-77.

5. Achmetjeva, N. P.; Štriter, E. E. Factors determining susceptibility of groundwater to corruption by compounds of nitrogen (ISSN 0235-2524). Reclamation and water есопоту (Мелиорация и водное хозяйство), № 2, 2002, p 16-18 (in Russian).

6. Leonavičiūte, N. Application of groundwater vulnerability model under Lithuanian conditions (ISSN 0132-3156). Annals of Geography (Geografijos metraštis), No 30, Vilnius, 1997, p 360-368 (in Lithuanian).

7. Kinderis, Z. Principal factors modeling chemical composition of drainage water. Land Reclamation and Hydro-en- 
gineering (Melioracija ir hidrotechnika). Transactions of Lithuanian Agricultural Academy, XIV 5(35), Vilnius: Mintis, 1968, p 10-19 (in Russian).

8. Kutra, G.; Aksomaitienè, R.; Petrokienè, Z. Influence of organic matter amendments on soil physical properties and nutrient leaching: results of field plot and laboratory tests in 1991-1995. Transactions of the Lithuania Institute of Water Management and University of Agriculture, Vol 1(23), Kaunas-Akademija, 1996, p 176-186.

9. Bučienè, A.; Ramoška, E.; Lukianienè, D. Dependence of plant nutrient leaching upon physical properties of soil (ISSN 1392-2335). Water Management Engineering, Transactions, 13(35). Kaunas-Akademija, 2000, p 40-48 (in Lithuanian).

10. Motuzas, A. Ecological estimation of Lithuanian arable soil contamination with mineral compounds in the context of soil science and agrochemistry development. Abstract of Doctor Habilitus dissertation. Kaunas, 2000, p 57-58 (in Lithuanian).

11. Juškauskas, J. Concentration dynamics of nitrogen combinations in underdrainage water from meadows (ISSN 13920200). Agricultural science (Žemès ūkio mokslai), No 2, Vilnius, 1998, p 73-79 (in Lithuanian).

12. Environmental condition 2001. Ministry of Environment of the Republic of Lithuania. Vilnius, 2002. 145 p (in Lithuanian).

13. LST ISO 5667-11 Water quality, Sampling. Part 11: Gui- dance on sampling of groundwaters. Vilnius, 1998, p 1-4 (in Lithuanian).

14. LST ISO 5667-3 Water quality, Sampling. Part 3. Guidance on preservation and handling of samples. Vilnius, 1998. 25 p (in Lithuanian).

15. Klimas, A. Fresh groundwater quality formation regularities under technogenic impacts. Vilnius, 1994. 56 p.

16. Steen, I. Putting the concept of environmentally balanced fertilizer recommendations into practice on the farm. In: Fertilizers and Environment. Netherlands, 1996, p 563564.

17. Tyla, A. Content of chemical nutrients in water reservoirs in a territory with increased fertilization. Farming and water quality. Proceedings, Kaunas, 1992, p 73-75 (in Lithuanian).

18. Groundwater monitoring in Lithuania 2002. Bulletin. Vilnius, 2003, p 14-30 (in Lithuanian).

19. Modelling and prognosing of dynamics of nitrogen compound penetration into wells. Report of research (Chief of the work A. Kusta). Lithuanian University of Agriculture, 1997, p 30-40 (in Lithuanian).

20. Tyla, A.; Rimšelis, J.; Šleiny, R. Leaching of nutrient matter of plants in different soils. Lithuanian Institute of Agriculture, Dotnuva-Akademija, 1997. 25 p (in Lithuanian).

21. Groundwater monitoring in Lithuania 1997. Bulletin. Vilnius, 1998, p 18-25 (in Lithuanian).

\section{NITRATŲ KIEKIO GRUNTINIAME VANDENYJE PRIKLAUSOMYBĖ NUO GAMTINIŲ VEIKSNIŲ}

\section{A. Pocienè, S. Pocius}

$\mathrm{S}$ a n t r a u k a

Požeminius vandenis su aplinka sieja aeracijos zona. Per ją įsifiltruoja krituliai, papildantys požeminio vandens išteklius, per ją iš žemès paviršiaus i gruntinį vandeningaji sluoksnị patenka ir įvairūs teršalai. Tik nuo jos storio ir laidumo priklauso, kokios medžiagos ir kada pasieks požeminius vandenis. Gruntiniai vandenys, esantys tarp paviršinių ir tarpsluoksninių, padeda sulaikyti ir transformuoti teršalus. Gruntinio vandens cheminès sudèties kitimas yra sudètingas procesas ir priklauso nuo įvairių veiksnių. Vertinant vandens kokybę, pagrindinis rodiklis yra nitratų koncentracija gruntiniame vandenyje ir bendrojo azoto koncentracija paviršiniame vandenyje. Dèl to reikia nustatyti, nuo ko daugiausiai priklauso nitratų koncentracijos gruntiniame vandenyje. Tyrimai atlikti 1997-2002 m. Lietuvos žemès ūkio universiteto mokomojo ūkio Karkiškių objekte bei remtasi mokslinèje literatūroje skelbiamais duomenimis. Buvo tiriamas gruntinio vandens lygio režimas ir nitratų kiekis. Darbo tikslas - nustatyti nitratų koncentracijos gruntiniame vandenyje ir gamtinių veiksnių: granuliometrinės dirvožemio sudèties, molio dalelių bei humuso kiekio dirvožemyje, gylio iki gruntinio vandens lygio, vandensparos gylio bei iškritusių per metus kritulių kiekio - sąsajas. Šių veiksnių sąveikai nustatyti taikyta koreliacinè analizè. Gruntinio vandens cheminè sudètis, kartu ir jo kokybè, labiausiai priklauso nuo gruntų, kuriuose jis susikaupęs. Kaip parodè mūsų atlikti tyrimai, azoto koncentracijai gruntiniame vandenyje, kartu ir kiek nitratinio azoto išplaunama, ittakos turi humuso bei molio dalelių kiekis dirvožemyje. Humuso kiekio itaka šiuo atžvilgiu priklauso ir nuo auginamų kultūrų. Lizimetriniai tyrimai rodo, kad didejjant molio dalelių kiekiui, azoto išplaunama mažiau. Tyrimais nustatytos gruntinio vandens slūgsojimo gylio, iškritusių kritulių kiekio ir nitratų koncentracijos gruntiniame vandenyje priklausomybès. Sąsajos pakankamai akivaizdžios, koreliacijos koeficientai dideli $(0,86-0,98)$.

Raktažodžiai: gruntinis vanduo, tarša, nitratai, gamtiniai veiksniai, krituliai, humusas, vandens kokybė, vandenspara.

\section{ЗАВИСИМОСТЬ КОЛИЧЕСТВА НИТРАТОВ В ГРУНТОВОЙ ВОДЕ ОТ ПРИРОДНЫХ ФАКТОРОВ}

\section{А. Поцене, С. Поцюс}

P е 3 ю м е

В Литве для питья в основном используют подземную воду. Воздействие различных факторов на процесс формирования химического состава грунтовых вод происходит комплексно, однако мера воздействия каждого из них в конкретной обстановке неодинакова. Грунтовые воды, пространственно занимая промежуточное положение между поверхностными и 
напорными, способствуют задержанию и трансформации загрязняющих веществ. Качественные изменения грунтовых вод или степень их загрязнения обусловливаются их уязвимостью. Различают два типа уязвимости: общую, обусловленную природными факторами, и специальную - уязвимость по отношению к определенному загрязнителю. Основными факторами, влияющими на содержание нитратов в грунтовой воде, являются содержание глинистых частиц в породах зоны аэрации и гумуса в почве, глубина до уровня грунтовой воды и водоупора, количество осадков, выпавших за год. Влияние гумуса на содержание $\mathrm{N}-\mathrm{NO}_{3}$ в грунтовой воде не однозначно. Большое количество глинистых частиц в грунтах зоны аэрации заметно снижает содержание $\mathrm{N}-\mathrm{NO}_{3}$ в грунтовых водах. Как показали наши исследования, на содержание нитратов также влияют глубина уровня грунтовых вод и глубина водоупора.

Ключевые слова: грунтовая вода, загрязнение, нитраты, природные факторы, осадки, гумус, качество воды, водоупор.

Alma POCIENE். Dr, Assoc Prof, Land Reclamation Department, Lithuanian University of Agriculture, Universiteto g. 10, LT-53361 Kaunas-Akademija, Kauno r., Lithuania. E-mail: almap@hidro.lzuu/lt

Doctor of Science (environmental engineering), 1977. Publications: author of more than 40 research papers. Research interests: environmental engineering and landscape management, land reclamation.

Skirmantas POCIUS. BSc, head of Prienai Environmental Protection Agency, Kęstučio g. 32, LT-59129 Prienai, Lithuania. E-mail: s.pocius@ard.am.lt

Bachelor of Science (hydraulic engineering), Lithuanian University of Agriculture, 1992. Publications: co-author of 6 research papers. Research interests: environmental engineering. 